\title{
Interventional treatment of moderate and severe mitral stenosis
}

\author{
Tomasz Bochenek, Michał Lelek, Magdalena Mizia, Marek Grabka, Anna Rybicka-Musialik, \\ Katarzyna Mizia-Stec
}

I Division and Department of Cardiology, Medical University of Silesia, SPSK7, Katowice

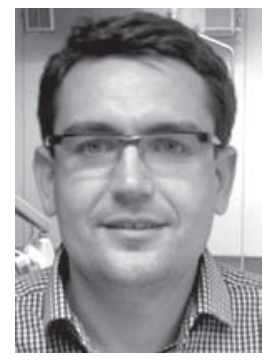

Kardiochirurgia i Torakochirurgia Polska 2013; 10 (2): 110-114

\begin{abstract}
Mitral valve stenosis (MS) is becoming relatively rare. However, it was revealed in $12.1 \%$ of Euro Heart Survey participants suffering from single native left-sided valve diseases; most of these MS cases were rheumatic in origin. Echocardiographic study is a gold diagnostic standard for MS, and it includes transthoracic, transesophageal, and three dimensional evaluation. Accurate echocardiographic assessment has therapeutic implications. Interventional treatment should be considered in symptomatic patients with moderate to severe mitral stenosis (mitral valve area $[\mathrm{MVA}] \leq 1.5 \mathrm{~cm}^{2}$ ). Currently, percutaneous mitral commissurotomy (PMC) is the recommended method of treatment; the safety and efficacy of this procedure are particularly dependent on echocardiographic evaluation. According to the current ESC guidelines, a surgical approach is recommended primarily in cases in which there are contraindications to PMC. In the study presented below, we describe the current guidelines for the interventional treatment of the defect, the practical aspects of qualifying patients for PMC, and the rules for performing PMC.
\end{abstract}

Key words: mitral stenosis, percutaneous valvuloplasty, echocardiography.

\section{Introduction}

Mitral stenosis (MS) is a well-known valvular heart defect and its description occupies a prominent position in every cardiology textbook. It was first described 300 years ago by the French physician De Vieussens [1]. Currently, the defect is diagnosed relatively rarely in European countries, due to the declining number of patients with rheumatic disorders [2]. In rare cases, MS may be a congenital defect, a complication of systemic disorders [3], a toxic effect of medications (including fenfluramine), a result of degenerative calcification, hypereosinophilia, or the presence of vegetation. Even

\section{Streszczenie}

Zwężenie zastawki mitralnej (mitral stenosis - MS) jest obecnie coraz rzadziej spotykaną nabytą wadą serca. Wśród uczestników rejestru Euro Heart Survey MS występowało u 12,1\%, a w większości opisywanych przypadków miało etiologię reumatyczną. Złotym standardem w rozpoznawaniu MS jest kompleksowe badanie echokardiograficzne obejmujące obrazowanie przezklatkowe, przezprzełykowe, a także trójwymiarowe. Dokładna ocena echokardiograficzna ma implikacje terapeutyczne. Leczenie interwencyjne należy rozważyć u chorych mających objawy z klinicznie istotnym - umiarkowanym lub ciężkim - MS (powierzchnia zastawki $\leq 1,5 \mathrm{~cm}^{2}$ ). Zalecaną obecnie metodą leczenia MS jest przezskórna komisurotomia mitralna (percutaneous mitral commissurotomy - PMC) - zabieg, którego bezpieczne i skuteczne przeprowadzenie w szczególności zależy od oceny echokardiograficznej. Zgodnie z obecnymi wytycznymi European Society of Cardiology leczenie operacyjne MS stosowane jest głównie w przypadku istnienia przeciwwskazań do przezskórnej walwuloplastyki. W niniejszej pracy przedstawiono aktualne zalecenia $w$ leczeniu zabiegowym wady, w szczególności praktyczne aspekty kwalifikacji do PMC i zasady jej wykonania.

Słowa kluczowe: stenoza mitralna, przezskórna walwuloplastyka, echokardiografia.

though the clinical picture of the defect is typical and its diagnosis should not pose a challenge, its declining frequency implies that the experience of medical centers in treating it is also decreasing. Below we present important practical aspects of qualifying patients for percutaneous mitral commissurotomy (PMC) and of performing this procedure.

\section{Imaging}

Echocardiographic examination is the gold standard in MS diagnosis; it includes transthoracic, transesophageal, and 3D imaging. The echocaridography results allow for

Address for correspondence: $\mathrm{dr}$ med. Tomasz Bochenek, I Division and Department of Cardiology, SPSK7, Ziołowa 45/47, 40-635 Katowice, tel. +48660689250, e-mail: tbochun@poczta.onet.pl 
determining the stage of advancement of the disease (Table I) and form the basis for qualifying patients for surgery and selecting the appropriate type of intervention (Fig. 1). 1- and 2D imaging aids the evaluation of structural changes in the mitral complex: the thickening and calcification of cusps, commissures, the mitral annulus, and the subvalvular apparatus. The examination helps to determine the degree to which cusp mobility is reduced - the literature provides numerous descriptions of posterior valve cusp immobility, cupuliform shape of the anterior cusp or its swinging movement. The currently recommended method for determining the stage of advancement of the defect is to conduct planimetric evaluation of the mitral valve area (MVA). The evaluation should be conducted in short axis parasternal projection, preferably at different levels in order to measure the most narrow cross-section of the valvular opening. Another recommended evaluation method

Table I. Mitral valve stenosis - echocardiographic criteria

\begin{tabular}{lccc} 
& Mild & Moderate & Severe \\
MVA $\left(\mathrm{cm}^{2}\right)$ & $>1.5$ & $1-1.5$ & $<1$ \\
\hline Mean MVG $(\mathrm{mm} \mathrm{Hg})$ & $<5$ & $5-10$ & $>10$ \\
\hline PASP $(\mathrm{mm} \mathrm{Hg})$ & $<30$ & $30-50$ & $>50$ \\
\hline $\begin{array}{l}\text { MVA - mitral valve area; MVG - mitral valve gradient; PASP - pulmonary artery } \\
\text { systolic pressure }\end{array}$
\end{tabular}

is the analysis of the mean transvalvular gradient. In practice, for evaluating the degree of constriction of the mitral valve, several other auxiliary methods are used, assessing the parameters of pressure half-time $(\mathrm{PHT})$, continuity equation, and proximal flow convergence zone. One should remember that evaluating the MVA by means of these indicators may be falsified in many clinical situations, e.g. in cases of abnormal left ventricular relaxation (prolongation of the PHT), atrial fibrillation (hemodynamic parameter values should be averaged within the range of 5-10 cardiac cycles). Special attention is required when MS is concomitant with insufficiency. It should be remembered that in such cases the measurements of the MS stage by means of parameters dependent on mitral inflow (mean transvalvular gradient, continuity equation, proximal flow convergence) will overestimate the degree of constriction. Concurrently, the quantitative assessment of insufficiency is crucial when deciding whether to perform a PMC or replace the valve.

Echocardiography also demonstrates structural and functional cardiac changes secondary to MS, including: left ventricular enlargement, the presence of clots in the left atrial auricle, and signs of pulmonary hypertension: shortened acceleration time of the inflow through the pulmonary ar-

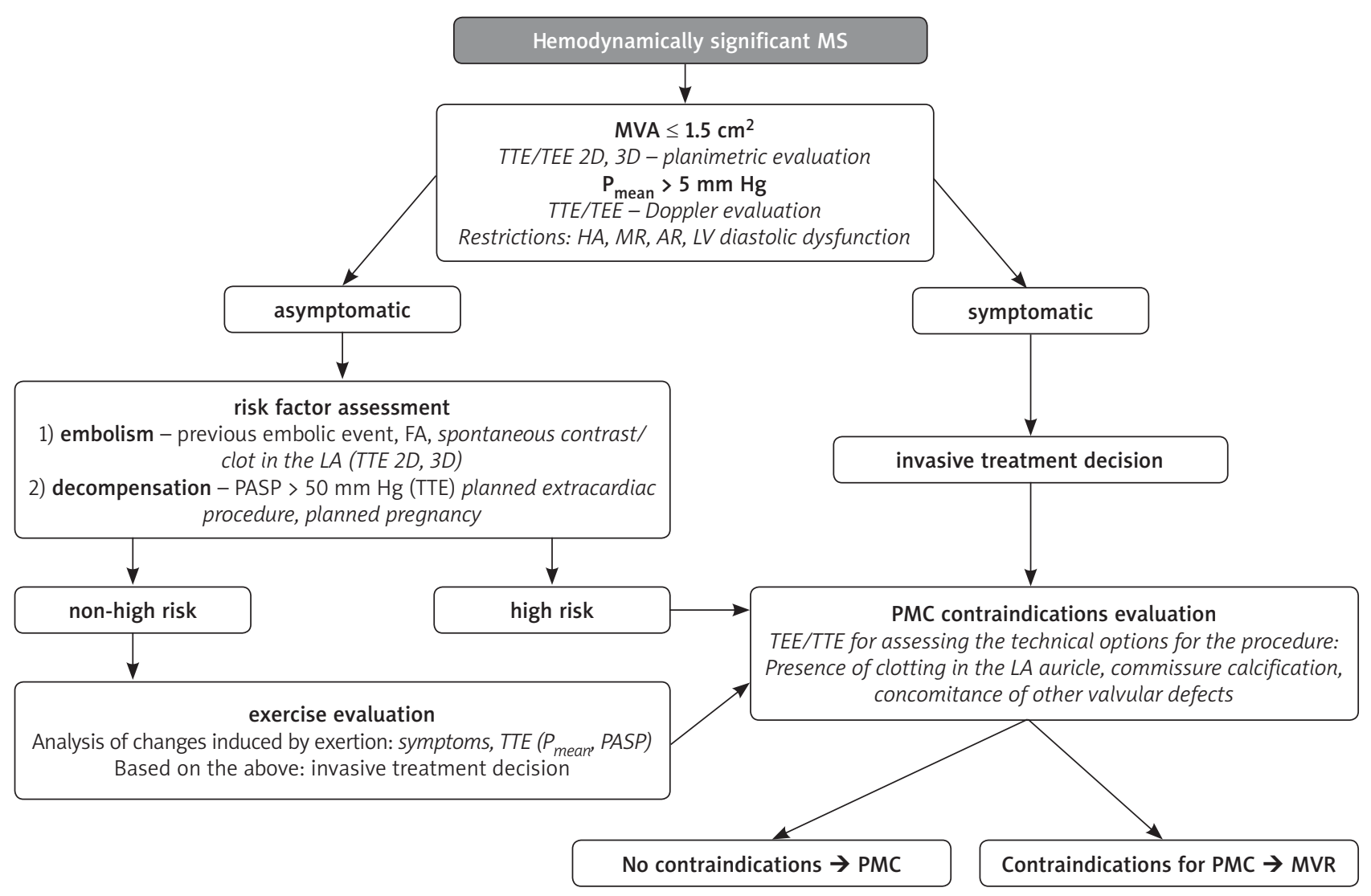

MS - mitral stenosis; MVA - mitral valve area; TTE - transthoracic echocardiogram; TEE - transesophageal echocardiography; HA - hypertension; MR - mitral regurgitation; AR - aortic regurgitation; LV - left ventricle; PASP - pulmonary artery systolic pressure; PMC - percutaneous mitral commissurotomy; MVR - mitral valve replacement

Fig. 1. A procedural scheme for hemodynamically significant mitral valve stenosis 

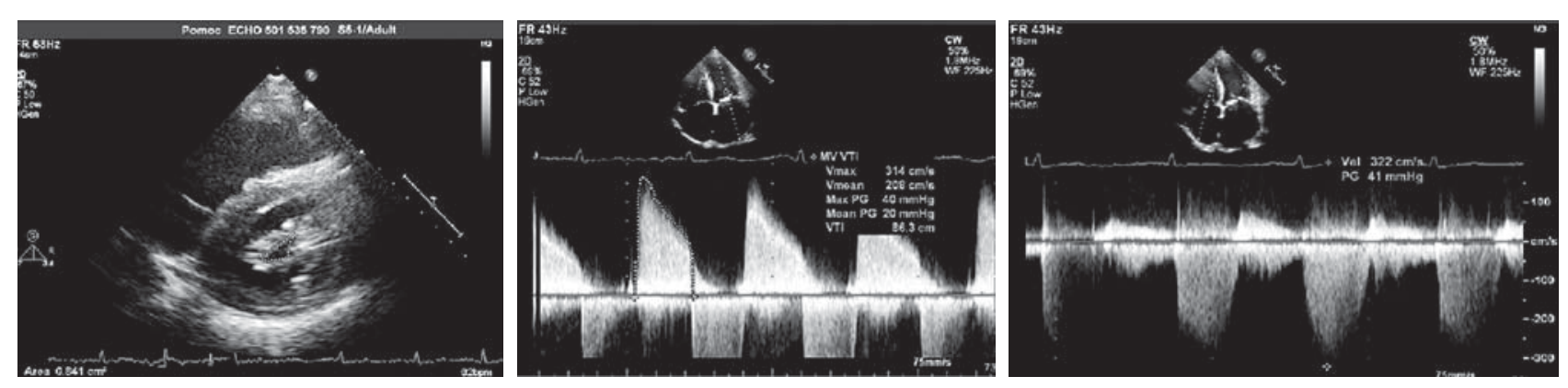

Fig. 2. Echocardiographic parameters used in assessing mitral valve stenosis (Area, $P_{\text {max }}, P_{\text {mean }}, R V S P$ )

tery valve $<80 \mathrm{~ms}$ and, in the case of patients with tricuspid valve insufficiency, right ventricular systolic pressure (RSVP) (Fig. 2). This information is critical for making therapeutic decisions.

The remaining elements of standard echocaridographic examination should not be omitted as some of them have prognostic value; this is particularly true of the indicators of left and right ventricular function. It is also important to determine the degree of tricuspid insufficiency - not only as an indirect exponent of RVSP, but also as a potential target for cardiac surgical intervention.

3D echocardiography is an invaluable method for assessing the degree of MS. It allows for the most precise MVA evaluation by identifying the location of the most significant constriction. The advantage of 3D echocardiography is that it offers the possibility of pinpointing the exact location of calcification and determining whether it is situated on the commissures. It enables the precise visualization of the subvalvular apparatus and the detection of, e.g., damage to the chordae tendineae, their fibrosis, or the presence of calcification.

The precision of the echocardiographic evaluation has therapeutic implications, as interventional treatment should be considered in cases of symptomatic patients with clinically significant (moderate or severe) MS (valve area $\leq 1.5 \mathrm{~cm}^{2}$, mean transvalvular gradient $>5 \mathrm{~mm} \mathrm{Hg}$ ). In the case of asymptomatic patients with the aforementioned degree of constriction, the decision concerning interventional treatment depends on the presence of high-risk predictors of embolism (a previous embolic event, atrial fibrillation, spontaneous left atrial echo contrast) or decompensation (pulmonary artery systolic pressure (PASP) $>50 \mathrm{~mm} \mathrm{Hg}$ at is also helpful at this stage of the patient qualification proceedings. If the aforementioned indicators are not present, post-exercise echocardiography evaluation is recommended.

The currently recommended treatment method for MS is PMC - the safety and efficiency of this procedure are particularly dependent on echocardiographic evaluation. The stages of clinical and echocardiographic evaluation have been presented above. At the same time, the qualification process for PMC employs the Wilkins score, which considers the following aspects of valvular morphology: mobility, thickening, and calcification of cusps, and thickening of the subvalvular apparatus. These aspects are rat- ed on a scale from 1 to 4 and the patient receives a score of 0 to 16 points. Valvuloplasty has been proven to be most advantageous for those patients who receive a score of less than 8; however, it should be noted that higher scores do not necessarily exclude the possibility of successful valvuloplasty. The Wilkins score was first developed on the basis of the examination of 22 patients who underwent percutaneous procedures. Its considerable limitation concerning PMC is the lack of a criterion for determining the anatomy of the commissures. In the opinion of the authors, this criterion is immensely important when qualifying patients for surgery - the procedure is meant to "rip apart" the commissures, so defects not involving the commissures cannot be safely treated by this method. Another classification used for assessing and qualifying mitral stenosis is the less frequently used Cormier score.

\section{Surgical treatment \\ Repair surgery}

Closed commissurotomy of the bicuspid valve using the left anterolateral thoracotomy approach is no longer performed by physicians in Europe. Nonetheless, the procedure did offer immediate effects, and many patients survived without the need for reoperation [4]. In developing countries, closed mitral commissurotomy has been replaced by open-heart commissurotomy with extracorporeal circulation using a median sternotomy approach, which involves not only the repair of fused valvular commissures, but also the correction of the subvalvular apparatus, thanks to direct visualization. In 2003, Kumar Choudhary published a paper in the "Annals of Cardiothoracic Surgery", which demonstrated the method's efficacy in a group of 276 patients, in whom contraindications for mitral valvuloplasty were found [5]. In spite of its advantages over closed commissurotomy, open-heart commissurotomy has currently been replaced by other, more advanced methods - valve replacement or PMC.

\section{Valve replacement}

According to the current ESC guidelines, surgical treatment of MS is employed mostly in cases in which there are contraindications for percutaneous valvuloplasty. Perioperative mortality varies within the range of 3-10\%; 
these values correlate with the patient's age, cardiac insufficiency class, the presence of pulmonary hypertension and the concomitance of coronary disease [6]. In Europe, the surgical treatment of mitral stenosis consists mostly in valve replacement. The valves are replaced using either traditional sternotomy or, as recent examples demonstrate, robotic cardiac surgery. In the "Journal of Thoracic and Cardiovascular Surgery", Gao presents encouraging surgery results in a small group of 22 patients and describes the procedure as safe and very promising [7].

\section{Percutaneous treatment of mitral stenosis}

Mitral valvuloplasty was first performed by the Japanese surgeon Kanji Inoue. Symptomatic patients with moderate or tight MS are qualified for the procedure. The key qualifying criterion is, obviously, the lack of contraindications. Currently, there are four main contraindications for percutaneous mitral valvuloplasty: the presence of clots in the left atrial auricle, concomitant moderate or severe mitral insufficiency, significant calcification in the mitral apparatus, and the presence of a significant aortic defect or another defect/disease of the coronary arteries requiring surgical correction. It has been demonstrated that the presence of significant calcification of the mitral valve commissures is an adverse prognostic factor - the patients from this group had lower survival and required surgical valve replacement more often [8]. Percutaneous mitral valvuloplasty can be employed if there are contraindications for surgery or as a bridge to final surgery. The best results are achieved in patients with fused commissures of the cusps.

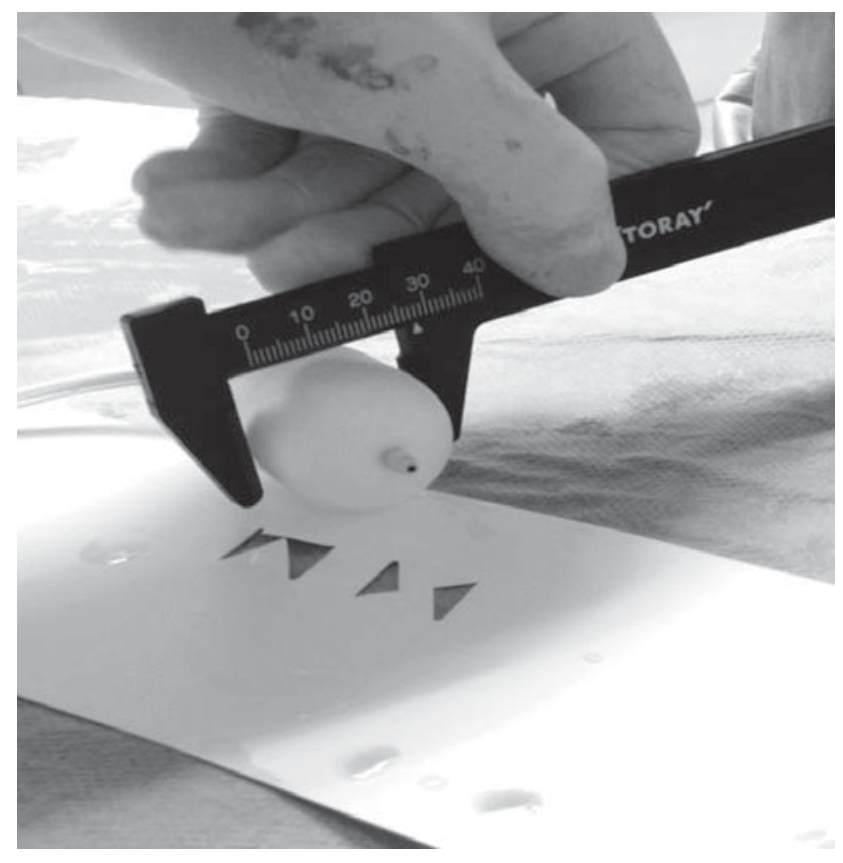

Fig. 3. Measuring the balloon for mitral valvuloplasty. The balloon is filled with a mixture of physiological saline and a contrast medium
Our medical center performs valvuloplasty employing the technique of Inoue. Preoperatively, the patient receives $1.0 \mathrm{~g}$ of cefazolin intravenously. Following the puncture of the femoral artery and ventriculography, a pigtail catheter is inserted into the aortic bulb, where it becomes a marker facilitating the performance of a transseptal puncture. The puncture is conducted using a femoral vein approach, under fluoroscopic and TEE (transesophageal echocardiography) control, which enhances the safety of the procedure. After the puncture of the interatrial septum, the patient is administered heparin. Subsequently, a special steel guide wire with a characteristically shaped spiral distal end is delivered to the left atrium through the catheter in the septum. The next stage of the procedure consists in dilating the femoral artery and the location of the puncture with a 14 F dilator. An Inoue balloon, selected based on the patient's height, is then introduced into the left atrium via the guide wire (Fig. 3). The balloon's distal part is partially filled and inserted into the left ventricle by means of a special flexible mandrin, which facilitates control over the balloon catheter (Fig. 4). After ensuring that the balloon did not pass between chordae tendineae and can be moved freely in the left ventricle, dilation of the mitral valve is performed. The exceptional structure of the Inoue balloon, which consists of two layers of rubber separated by a synthetic microgrid layer, enables its sequential filling. During the first stage, the distal part of the balloon is filled, and the subsequent filling of the proximal part stabilizes the balloon in the mitral opening (Fig. 5). Finally, the middle part fills up, ripping apart the fused mitral valve commissures. After the balloon is emptied, it is removed to the left

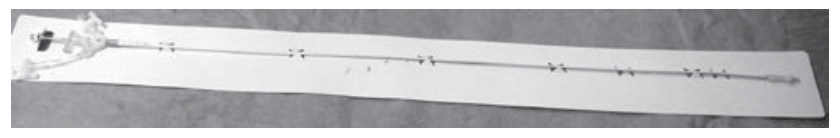

Fig. 4. A balloon catheter for valvuloplasty

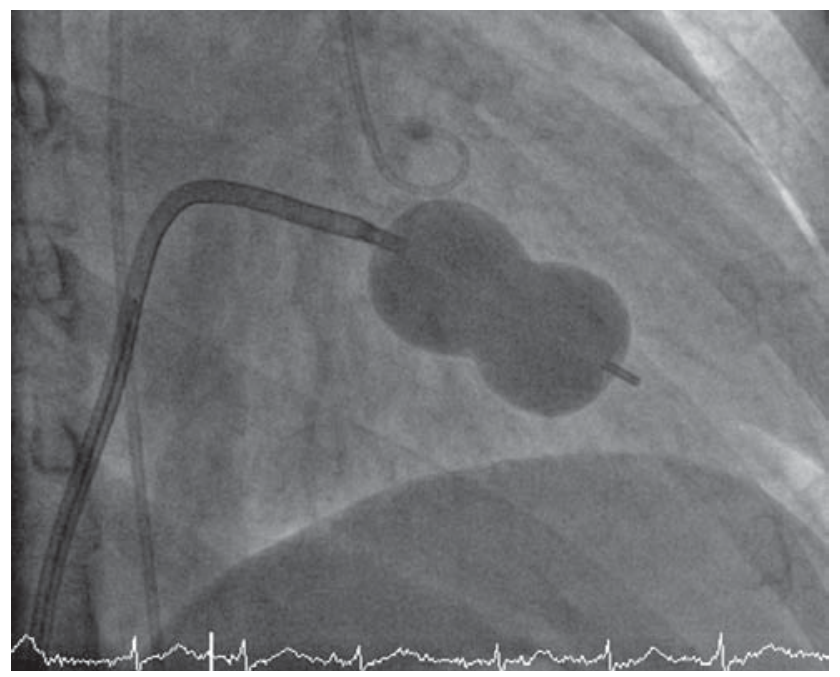

Fig. 5. A filled balloon in the mitral position (the moment of balloon inflation and valve distention) 
atrium, and hemodynamic and echocardiographic measurements are conducted. If repeated dilation of the valve is required, the steps of the procedure are performed again, but the balloon is filled with a larger volume of the mixture of physiological saline and a contrast medium.

Below we present the cases of two patients recently treated for MS in our clinic - one of them received interventional percutaneous treatment, while the other one was treated surgically.

\section{Patient C.Z.}

The patient, suffering from persistent atrial fibrillation, MS, chronic circulatory insufficiency, exertional dyspnea, and periodical chest pains (both exertional and at rest), was admitted to the ward due to decreasing exercise tolerance. Transthoracic and transesophageal echocardiography revealed normal systolic function of the left cardiac ventricle [ejection fraction $(E F)=50 \%$ ], severe MS (MVA: $0.6-0.7 \mathrm{~cm}^{2}, P_{\text {mean }}$ : $13 \mathrm{~mm} \mathrm{Hg}$ ), mild aortic valve stenosis, left atrial dilatation, and echogenic blood (class IV) within the left atrium. The patient's Wilkins score was 10 (indicating possible success of a percutaneous procedure). Non-critical changes in the coronary arteries were found by means of coronarography. During the cardiac surgery consultation, the patient was qualified for a PMC procedure. The procedure was conducted utilizing a transseptal puncture; a satisfactory effect was attained after 3 balloon inflations (diameters: 24 and $28 \mathrm{~mm}$ ). The postoperative course was uneventful. Follow-up echocardiographic examination revealed an increase of the MVA to $1.8 \mathrm{~cm}^{2}$; the patient reported a subjective improvement in her well-being and exercise tolerance. She was discharged after 6 days of hospitalization in good general condition.

\section{Patient M.A.}

The patient was admitted to the ward with paroxysmal atrial fibrillation, MS, chronic renal failure, and signs of NYHA IV. Transthoracic and transesophageal echocardiography revealed impaired systolic function of the left cardiac ventricle $(E F=40 \%)$, severe $M S\left(M V A: 1.0 \mathrm{~cm}^{2}, P_{\text {mean }}\right.$ : $10 \mathrm{~mm} \mathrm{Hg}$ ), dilatation of the left atrium, and the presence of clots in the auricle of the left atrium. A constriction in the anterior descending artery was revealed by coronarography; its significance was confirmed with a fractional flow reserve (FFR) measurement. During the cardiac surgery consultation, the patient was qualified for a classical cardiac procedure of valve replacement and CABG (LIMA-LAD). There were no significant postoperative complications. Follow-up echocardiography confirmed normal function of the mitral prosthesis. The patient was discharged and sent home after 10 days of hospitalization.

\section{Conclusions}

Modern diagnostic and treatment methods allow for the efficacious treatment of patients with MS. Percutaneous mitral valvuloplasty plays an important role in therapy and is currently considered to be a therapy of choice in such cases. Decisions concerning the procedure should be made jointly by a so-called "heart team" in order to warrant the safety of the procedure and to make sure that it will be advantageous to the patient's well-being and their long-term prognosis.

\section{References}

1. De Vieussens R. Nouvelles Decouvertes sur le coeur. Laurent d'Houry, Paris 1706.

2. Iung B, Baron G, Butchart EG, Delahaye F, Gohlke-Bärwolf C, Levang OW, Tornos $P$, Vanoverschelde JL, Vermeer F, Boersma E, Ravaud P, Vahanian A. A prospective survey of patients with valvular heart disease in Europe: The Euro Heart Survey on Valvular Heart Disease. Eur Heart J 2003; 24: 1231-1243.

3. Gąsior Z, Stępińska J, Podolec P, Ablewska U. Postępy w diagnostyce i leczeniu nabytych wad serca. Centrum Medyczne Kształcenia Podyplomowego, Warszawa 2011.

4. Antunes MJ, Vieira H, Ferrão de Oliveira J. Open mitral commissurotomy: the 'golden standard'. J Heart Valve Dis 2000; 9: 472-477.

5. Choudhary SK, Dhareshwar J, Govil A, Airan B, Kumar AS. Open mitral commissurotomy in the current era: indications, technique, and results. Ann Thorac Surg 2003; 75: 41-46.

6. Vahanian A, Alfieri O, Andreotti F, Antunes MJ, Barón-Esquivias G, Baumgartner H, Borger MA, Carrel TP, De Bonis M, Evangelista A, Falk V, Lung B, Lancellotti P, Pierard L, Price S, Schäfers HJ, Schuler G, Stepinska J, Swedberg K, Takkenberg J, Von Oppell UO, Windecker S, Zamorano JL, Zembala M; ESC Committee for Practice Guidelines (CPG); Joint Task Force on the Management of Valvular Heart Disease of the European Society of Cardiology (ESC); European Association for Cardio-Thoracic Surgery (EACTS). Guidelines on the management of valvular heart disease (version 2012): the Joint Task Force on the Management of Valvular Heart Disease of the European Society of Cardiology (ESC) and the European Association for Cardio-Thoracic Surgery (EACTS). Eur J Cardiothorac Surg 2012; 42: S1-44.

7. Gao C, Yang M, Xiao C, Wang G, Wu Y, Wang J, Li J. Robotically assisted mitral valve replacement. J Thorac Cardiovasc Surg 2012; 143 (4 Suppl): S64-S67.

8. Cannan CR, Nishimura RA, Reeder GS, Ilstrup DR, Larson DR, Holmes DR, Tajik AJ. Echocardiographic assessment of commissural calcium: a simple predictor of outcome after percutaneous mitral balloon valvotomy. J Am Coll Cardiol 1997; 29: 175-180. 